\title{
STATUS KEBERLANJUTAN PERIKANAN HUHATE BERDASARKAN ASPEK BIOLOGI DI PPI DUFA-DUFA KOTA TERNATE
}

\author{
Sustainability Status of Pole and Line Fisheries Based on Biology Aspects in PPI Dufa- \\ Dufa Ternate City \\ Oleh: \\ Irham ${ }^{*}$, Amirul Karman², Kusdi Hi Iksan ${ }^{3}$ \\ ${ }_{1}^{1}$ Program Studi MSP, Fakultas Perikanan dan Ilmu Kelautan, Universitas Khairun Ternate.inon_kair@yahoo.co.id \\ 2 Program Studi PSP, Fakultas Perikanan dan Ilmu Kelautan, Universitas Khairun Ternate. karmanamirul@yahoo.co.id \\ ${ }_{3}^{3}$ Program Studi PSP, Fakultas Perikanan dan Ilmu Kelautan, Universitas Khairun Ternate. ichsanpasca2@gmail.com
}

* Korespondensi: ichsanpasca2@gmail.com

Diterima: 17 Desember 2018; Disetujui: 22 Juli 2019

\begin{abstract}
Ternate Island lies in a strategic location as it is situated in the middle of the main fishing ground for skipjack (Katsuwonus pelamis) fishing using pole and line (huhate) and fish aggregating devices (FADs). As typical pelagic fish, skipjack that is gathered near the water surface is the younger fish, likewise the ones which are caught around FADs. Therefore, this fishing method has caused serious problem due to the domination of young fish and increasing bycatch and discard. The objective of this research is to analyze the size structure of the fork length, appropriate size for catching, catch composition, bycatch and discard level. Pole and line catch samples were collected in 3 months fromMay to July 2018. The results show that in average, skipjack tuna caught in the study location was undersize. The total catch is predominantly targeted fish which has a higher economic value compared to bycatch and discarded fish. Even though bycatch in the pole and line fisheries are low, reduction efforts are still required. which can be done by sorting bycatch and unwanted fish then discard it into the sea when the fish is still alive.
\end{abstract}

Keywords: biology, pole and line, sustainability status, Ternate City

\begin{abstract}
ABSTRAK
Posisi Pulau Ternate sangat strategis karena berada di tengah perairan yang menjadi daerah operasi penangkapan cakalang (Katsuwonus pelamis) dengan alat tangkap huhate (pole and line) yang dibantu dengan penggunaan rumpon. Sebagaimana ikan pelagis lainnya, ikan-ikan cakalang yang berkumpul di lapisan permukaan air cenderung tergolong ikan-ikan muda. Oleh karena itu, cakalang yang tertangkap di sekitar rumpon juga cenderung ikan-ikan yang masih muda. Fenomena ini menyebabkan munculnya sebuah masalah besar, yaitu dominasi ikan-ikan muda, selain itu juga sering tertangkap ikan yang bukan target tangkap yang terdiri dari bycatch dan discards. Tujuan dari penelitian ini adalah menganalisis struktur ukuran panjang cagak dan ukuran cakalang layak tangkap, komposisi hasil tangkapan, persentase bycatch dan discards. Sampel hasil tangkapan huhate dikumpulkan selama 3 bulan (Mei sampai Juli 2018). Hasil penelitian menunjukkan bahwa rataan cakalang di lokasi penelitian didominasi ukuran belum layak tangkap. Total hasil tangkapan didominasi ikan target, sementara itu bycatch yang tertangkap memiliki nilai ekonomis yang baik dan tidak ditemukan discards. Walaupun bycatch pada
\end{abstract}


perikanan huhate rendah namun usaha-usaha untuk meminimumkan tetap perlu dilakukan. Salah satu usaha yang bisa dilakukan adalah menyortir hasil tangkapan, ada apabila ada ikan yang akan dibuang ke laut, dilakukan dalam keadaan masih hidup.

Kata Kunci: Biologi, huhate (pole and line), status keberlanjutan, Kota Ternate

\section{PENDAHULUAN}

Sumber daya cakalang (Katsuwonus pelamis) adalah sumber daya yang dapat diperbarui. Artinya, jika sumber daya cakalang diambil sebagian, sisa yang tertinggal memiliki kemampuan untuk memulihkan populasi dengan cara berkembang biak. Hal ini menunjukkan bahwa stok atau populasi cakalang tidak boleh diambil atau dimanfaatkan secara sembarangan tanpa memperhatikan struktur umur ikan dan rasio kelamin dari populasi cakalang yang tersedia (Karman et al. 2014). Kemampuan memulihkan populasi yang rendah atau lambat, akan mengancam keberlanjutan sumber daya ikan. Cakalang termasuk jenis ikan yang memiliki keterbatasan dalam beregenerasi, sehingga kegiatan pemanfaatan sumber daya melalui peningkatan upaya penangkapan yang terusmenerus dapat mengancam keberlanjutan sumber daya yang ada. Kondisi ini memberikan peringatan bahwa pemanfaatan sumber daya cakalang harus dilakukan secara hati-hati (Karman et al. 2014).

Posisi Pulau Ternate sangat strategis, karena berada di perairan yang menjadi daerah operasi penangkapan cakalang. Nelayan yang melakukan penangkapan cakalang di perairan Kota Ternate menggunakan huhate, yang dalam istilah asingnya disebut pole and line, yang dilengkapi dengan alat bantu rumpon. Armada huhate ini berpangkalan di pangkalan pendaratan ikan (PPI) Dufa-Dufa.

Karman et al. (2016) menyatakan bahwa sebagaimana ikan pelagis lainnya, ikan-ikan cakalang yang berkumpul di lapisan permukaan air tergolong ikan-ikan yang muda. Oleh karena itu, cakalang yang tertangkap di sekitar rumpon juga cenderung ikan-ikan yang masih muda. Fenomena ini menyebabkan munculnya sebuah masalah besar, yaitu dominasi ikan-ikan muda dan sering ditemukannya bycatch dan discards pada pengoperasian huhate menggunakan rumpon di perairan Kota Ternate. Bycatch adalah tertangkapnya ikan-ikan yang bukan menjadi tujuan penangkapan, sedangkan discards adalah bycatch yang dibuang ke laut. Masalah ini dapat mengancam kelestarian sumber daya cakalang dan ikan lainnya yang beruaya di perairan Kota Ternate.
Penelitian tentang analisis sumber daya cakalang di berbagai wilayah Indonesia timur telah dilakukan oleh beberapa peneliti. Diantaranya adalah penelitian di perairan Kabupaten Pahuwato, Provinsi Gorontalo yang telah dilakukan oleh Tuli et al. (2014). Berdasarkan hasil uji ANOVA, beberapa faktor yang mempengaruhi tingginya jumlah tangkapan cakalang di Kabupaten Pohuwato adalah kedalaman, zona penangkapan dan jenis alat tangkap yang digunakan, sedangkan faktor musim tidak berpengaruh nyata dengan jumlah hasil tangkapan. Selanjutnya, Mallawa et al. (2018), meneliti keberlanjutan teknologi penangkapan cakalang di perairan Teluk Bone, Sulawesi Selatan yang menunjukkan bahwa huhate rumpon mencapai nilai keberlanjutan $57,50 \%$, huhate tanpa rumpon $76,88 \%$, pukat cincin $51,25 \%$, pukat cincin rumpon $48,75 \%$, payang $48,13 \%$ dan pancing tangan $68,13 \%$. Rendahnya tingkat keberlanjutan teknologi penangkapan disebabkan oleh dominannya ikan ukuran kecil dan rendahnya ikan ukuran layak tangkap, nilai investasi, tingkat pendapatan, penggunaan tenaga kerja dan BBM dan tertangkapnya biota laut yang dilindungi. Sementara itu, Utami et al. (2015), meneliti pengelolaan perikanan cakalang berkelanjutan dengan pendekatan bioekonomi di Kabupaten Flores Timur. Hasil yang diperoleh dalam penelitian ini adalah dalam kurun waktu 2003-2012 upaya pemanfaatan sumber daya cakalang belum mengalami gejala overfishing, sehingga kesempatan dalam upaya pemanfaatan sumber daya masih terbuka. Di Kabupaten Lombok Timur Provinsi Nusa Tenggara Barat, Gigentika (2014), meneliti strategi pengembangan perikanan cakalang yang menghasilkan 7 (tujuh) alternatif strategi pengembangan perikanan cakalang di Kabupaten Lombok Timur, yaitu mengoptimalkan pemanfaatan sumber daya cakalang, merasionalisasikan jumlah unit penangkapan cakalang, memberikan pelatihan kepada nelayan mengenai cara penanganan hasil tangkapan, memperbaiki kelembagaan nelayan untuk meningkatkan posisi tawar nelayan, memaksimalkan potensi pasar komoditi cakalang, serta diversifikasi jenis pengolahan cakalang. Selanjutnya Karman et al. (2016), meneliti basis biologi cakalang sebagai landasan pengelolaan perikanan berkelanjutan di Provinsi Maluku Utara, hasil penelitian menunjukkan nilai $b=3$ untuk 
cakalang yang tertangkap di sekitar rumpon zona $A$ dan $B$. Hal ini menunjukkan bahwa pertumbuhan cakalang di kedua zona tersebut berpola isometrik. Nilai $L \infty$ cakalang yang tertangkap zona A dapat mencapai $75 \mathrm{~cm}$ pada umur 56 bulan dan di zona B mencapai $76 \mathrm{~cm}$ pada umur 56 bulan. Nilai $L m$ cakalang yang tertangkap di zona A dan zona B diperoleh sebesar $43 \mathrm{~cm}$, dengan kisaran panjang cagak cakalang yang tertangkap di zona $A$ berkisar antara 26,0-72,0 cm, dan di zona B berkisar antara 26-71 cm. Tingkat kematangan gonad cakalang yang tertangkap di zona A dan zona $B$, diperoleh beberapa tingkat kematangan gonad yaitu TKG I, TKG II, TKG III, TKG IV, dan TKG V. TKG $V$ dari cakalang yang tertangkap di sekitar rumpon zona A ditemukan pada bulan Maret dan B pada bulan Juli, sehingga dapat diduga cakalang di kedua zona memijah sepanjang tahun dengan puncak terjadi pada bulan Maret untuk zona A dan Juli zona B. Mallawa (2016), meneliti struktur ukuran cakalang yang tertangkap nelayan huhate di sekitar dan luar rumpon perairan Luwu Teluk Bone Selatan, hasil penelitian menunjukkan bahwa struktur ukuran berbeda antara cakalang ditangkap di sekitar rumpon dan luar rumpon. Cakalang yang tertangkap di luar rumpon didominasi oleh cakalang berukuran besar dibandingkan yang ditangkap di sekitar rumpon.
Informasi mengenai status keberlanjutan perikanan huhate berdasarkan aspek biologi di PPI Dufa-Dufa Kota Ternate belum banyak diteliti dan alasan itulah yang mendasari dilakukannya penelitian ini. Tujuan dari penelitian ini adalah untuk menganalisis aspek biologi sumber daya cakalang meliputi struktur ukuran panjang cagak dan ukuran layak tangkap, komposisi hasil tangkapan, tingkat bycatch dan discards, serta untuk menganalisis keberlanjutan perikanan huhate. Hipotesis yang digunakan dalam penelitian ini adalah perikanan huhate di PPI Dufa-Dufa tidak berkelanjutan karena hasil tangkapannya didominasi cakalang muda (belum layak tangkap), bycatch dan discards.

\section{METODE}

Penelitian telah dilaksanakan di PPI Dufa-Dufa Kota Ternate, dari bulan Mei sampai September 2018 (Gambar 1). Lokasi ini dipilih karena merupakan salah satu pangkalan pendaratan cakalang dan dijadikan sebagai tempat pendaratan hasil tangkapan armada huhate di Provinsi Maluku Utara.

Metode dalam penelitian ini adalah metode survei deskriptif yang dilakukan dengan mengambil sampel hasil tangkapan huhate di

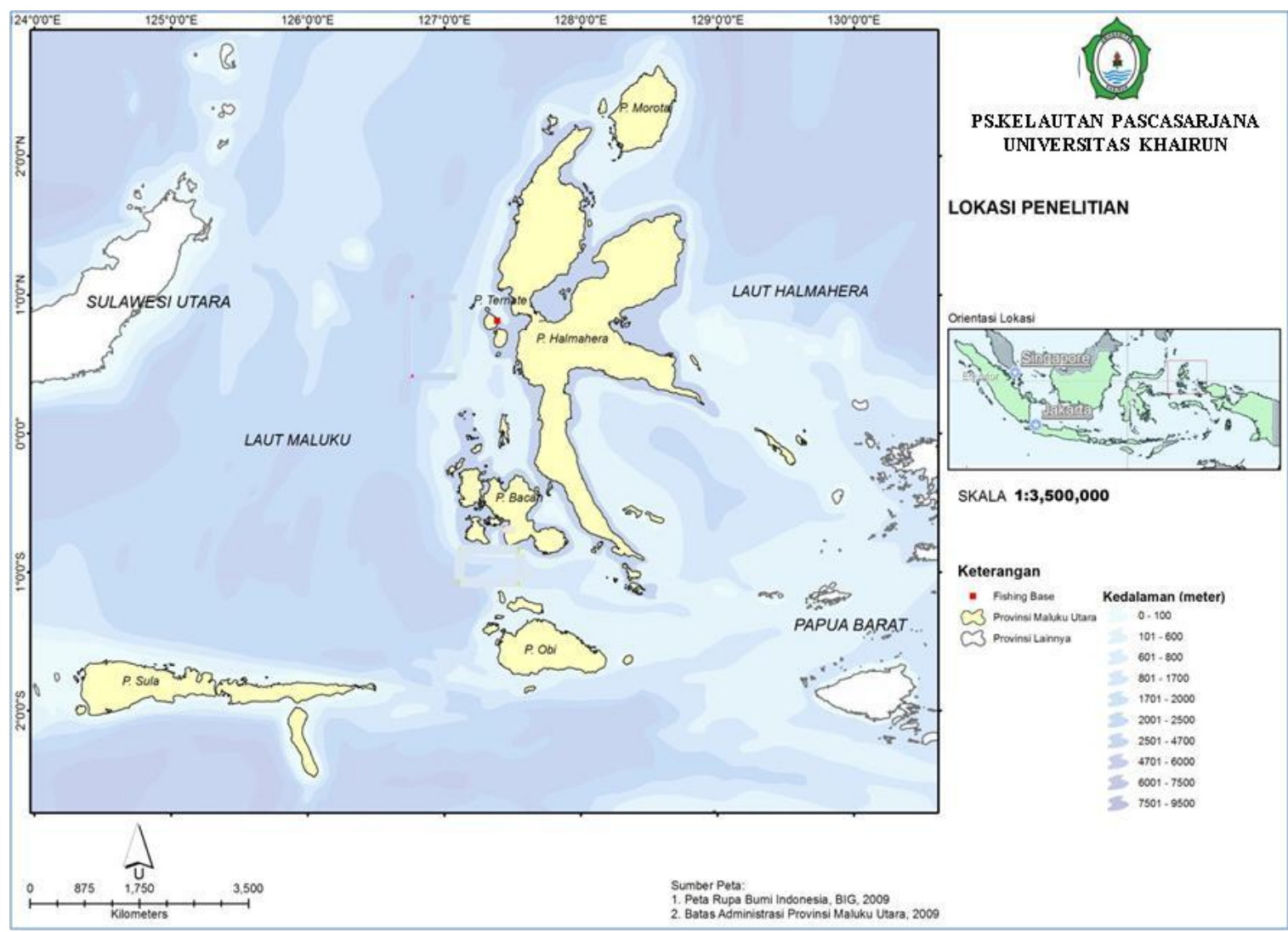

Gambar 1 Lokasi Penelitian 
Tabel 1 Beberapa nilai $L m$

\begin{tabular}{lccl}
\hline $\begin{array}{c}\text { Nilai Lm } \\
\text { FL }\end{array}$ & $\begin{array}{c}\text { Jenis } \\
\text { kelamin } \\
\text { ikan }\end{array}$ & Negara & \multicolumn{1}{c}{ Lokasi } \\
\hline $\left.43^{*}\right)$ & - & Indonesia & $\begin{array}{l}\text { Perairan Barat dan Selatan } \\
\text { Provinsi Maluku Utara }\end{array}$ \\
$\left.46^{* *}\right)$ & - & Indonesia & $\begin{array}{l}\text { Teluk Bone } \\
\left.38,03^{* * *}\right)\end{array}$ \\
\hline
\end{tabular}

$\left.{ }^{*}\right)$ Karman et al. (2016)

**) Jamal et al. (2011)

$\left.{ }^{* *}\right)$ Toatubun et al. (2015)

PPI Dufa-Dufa. Data biologi yang dikumpulkan adalah hasil tangkapan (jenis ikan), panjang (cm) dan berat (gram). Data panjang cagak/fork length (FL) dan berat yang diukur terbatas pada sampel cakalang yang dipilih secara purposive sampling, yaitu teknik non-random sampling dimana peneliti menentukan pengambilan sampel dengan cara menetapkan ciri-ciri khusus. Dalam hal ini, ciri khususnya adalah keterwakilan dari cakalang sampel berukuran kecil, sedang, dan besar dari kapal huhate KM. Inka Mina 521 yang mendaratkan hasil tangkapan di PPI Kota Ternate. Jumlah ikan sampel yang diukur panjang dan berat sebanyak 50 ekor per trip per minggu. Pengukuran panjang sampel ikan dilakukan selama 3 bulan (12 kali trip penangkapan) sehingga total sampel sebanyak 600 ekor. Pengukuran panjang cagak sampel cakalang menggunakan measuring board dengan ketelitian $0,1 \mathrm{~cm}$. Pengukuran berat menggunakan timbangan kapasitas $10 \mathrm{~kg}$ dengan ketelitian $0,1 \mathrm{~kg}$.

Pengolahan data dilakukan dengan statistik deskriptif yang ditampilkan dalam bentuk tabel dan diagram menggunakan aplikasi microsoft excel. Analisis keberlanjutan perikanan huhate dilakukan secara deskriptif berdasarkan kriteria struktur cakalang yang tertangkap pada ukuran yang layak, persentase bycatch dan discards. Cakalang layak tangkap adalah ukuran cakalang yang sudah melakukan pemijahan. Ukuran layak tangkap dan tidak layak tangkap dari struktur ukuran panjang cagak cakalang dilakukan secara deskriptif dengan merujuk pada hasil penelitian sebelumnya yang berkaitan dengan ukuran panjang cakalang pertama kali matang gonad (Tabel 1). Analisis persentase cakalang layak tangkap menggunakan motode Mallawa (2013) sebagai berikut:

Ikan layak tangkap $(\%)=\frac{\Sigma \text { Ikan layak tangkap }}{\Sigma \text { Hasil tangkapan }} \times \%$

Komposisi jenis hasil tangkapan dimaksudkan untuk membandingkan jenis hasil tangkapan untuk setiap kali trip penangkapan. Kemudian komposisi hasil tangkapan ditentukan berdasarkan kelimpahan relatif dari setiap jenis ikan dengan persamaan (2) (Sudirman et al. 2011). Jumlah hasil tangkapan setiap jenis ikan pada setiap trip dari masing-masing jenis ikan dideskripsikan menggunakan diagram pie.

$K r=\frac{H t}{T} \times 100 \%$

Keterangan:

$\mathrm{Kr}=$ Kelimpahan relatif ikan (\%)

$\mathrm{Ht}=$ Hasil tangkapan ikan (ekor)

$\mathrm{T}=$ Total hasil tangkapan (ekor)

Analisis frekuensi kemunculan setiap jenis ikan hasil tangkapan dihitung dengan rumus sebagai berikut (Kasmawati dan Andriana 2015):

$F r=\frac{J K}{T} \times 100 \%$

Keterangan:

$\mathrm{Fr}=$ Frekuensi relatif

$J K=$ Jumlah kemunculan setiap jenis ikan hasil tangkapan

$T=$ Total trip

Analisis bycatch dan discards dihitung dengan rumus sebagai berikut (Sudirman et al. 2011):

$T_{\text {bycatch }}=\frac{\sum \text { ByCatch }}{\text { Totaltangkapan }} \times 100 \%$

$T_{\text {discard }}=\frac{\sum \text { Discard }}{\text { Totaltangkapan }} \times 100 \%$

$T_{b d}=\frac{\sum \text { Bycatch dan Discard }}{\text { Total Tangkapan }}$

Keterangan:

$\mathrm{T}_{\mathrm{bd}}=$ Tingkat bycatcth dan discards

Status keberlajutan perikanan huhate dianalisis berdasarkan berdasarkan kriteria tingkat persentase ukuran cakalang layang tangkap, bycatch, dan discards. Acuannya bahwa jika ukuran cakalang kategori tidak layak tangkap, bycatch, dan discards memiliki persentase $>50 \%$, maka perikanan huhate di PPI DufaDufa Kota Ternate tidak berkelanjutan. 


\section{HASIL}

Struktur ukuran panjang cagak dan layak tangkap cakalang

Struktur ukuran panjang cagak/fork length (FL) cakalang yang tertangkap selama 3 bulan (Mei sampai Juli) memiliki kisaran antara 26-72 cm dengan nilai tengah kelas berkisar antara $28,0-73,0 \mathrm{~cm}$, panjang minimal nilai tengah kelas diperoleh pada bulan Juli yaitu $28,0 \mathrm{~cm}$, sedangkan panjang maksimal diperoleh pada Mei yaitu 73,0 cm. Bulan Mei panjang nilai tengah kelas didominasi ukuran 48 cm sebanyak 129 ekor, Juni didominasi panjang nilai tengah kelas $38 \mathrm{~cm}$ sebanyak 91 ekor, dan Juli didominasi panjang nilai tengah kelas $33 \mathrm{~cm}$ sebanyak 129 ekor (Gambar 2).
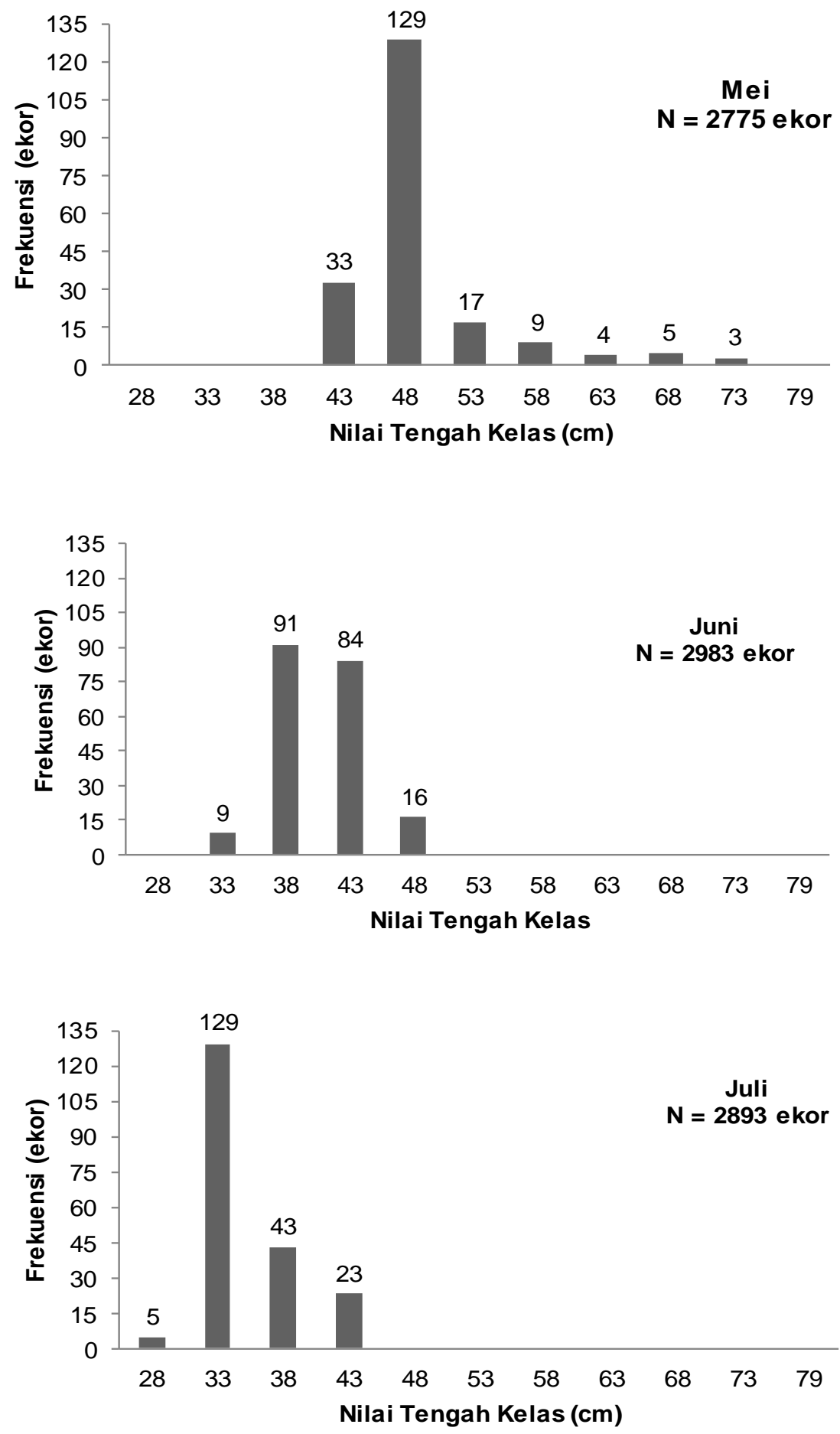

Gambar 2 Struktur ukuran cakalang yang tertangkap huhate dan didaratkan di PPI Dufa-Dufa Kota Ternate selama 3 bulan (Mei sampai Juli) 
Rataan FL menunjukkan trend menurun mulai dari bulan Mei sampai Juli. Nilai rataan ukuran $F L$ cakalang terkecil pada bulan Juli yaitu $34,9 \pm 3,9 \mathrm{~cm}$ dan terbesar pada Mei yaitu 48,99 $\pm 5,7 \mathrm{~cm}$ (Gambar 3). Range FL cakalang terbesar pada bulan Mei yaitu $29,5 \mathrm{~cm}$ sedangkan terkecil pada Juni yaitu $14,5 \mathrm{~cm}$ (Gambar 4). Nilai standar deviasi FL cakalang terbesar pada bulan Mei yaitu $5,7 \mathrm{~cm}$ dan terkecil pada Juni yaitu 3,5 cm (Gambar 5).

Berdasarkan hasil penelitian Karman et al. (2016) yang berkaitan dengan ukuran panjang cakalang pertama kali matang gonad (Tabel 1), maka cakalang yang tertangkap dengan huhate yang didaratkan di PPI Dufa-Dufa Kota
Ternate selama 3 bulan (Mei sampai Juli) didominasi ukuran belum layak tangkap, dimana dari 600 ekor sampel cakalang yang diukur memiliki rataan ukuran FL berkisar 34,95 - 40,54 $\mathrm{cm}$. Ukuran FL cakalang yang layak tangkap ditemui pada bulan Mei yaitu sebanyak 200 ekor (33,33\%). Sementara itu, ukuran ikan yang belum layak tangkap ditemukan pada bulan Juni dan Juli dengan jumlah masing-masing 200 ekor (33,33\%). Hal ini menunjukkan bahwa ukuran FL cakalang yang didaratkan di PPI Dufa-Dufa selama 3 bulan (Mei, Juni, dan Juli) didominasi ukuran cakalang yang belum layak tangkap yaitu sebesar $66,67 \%$ dari total sampel cakalang yang diukur (600 ekor) (Tabel 2).

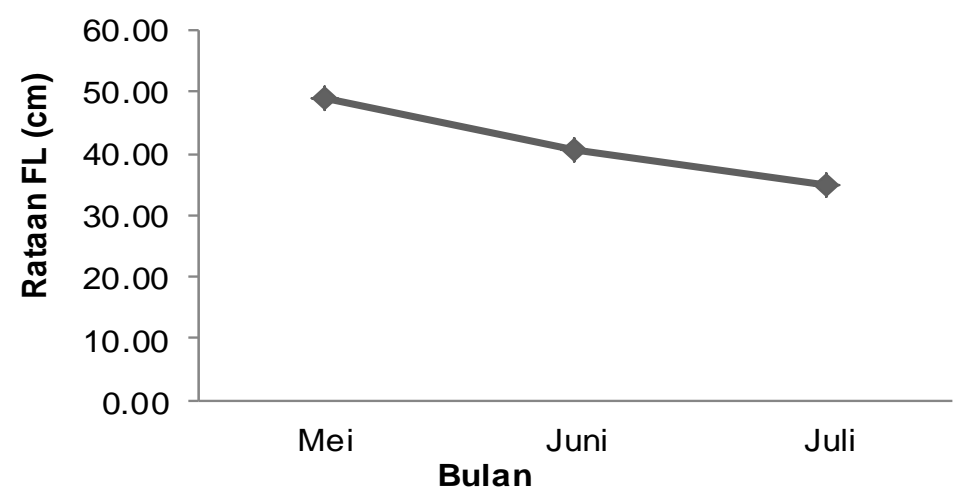

Gambar 3 Rataan panjang cagak cakalang yang didaratkan di PPI Dufa-Dufa Kota Ternate.

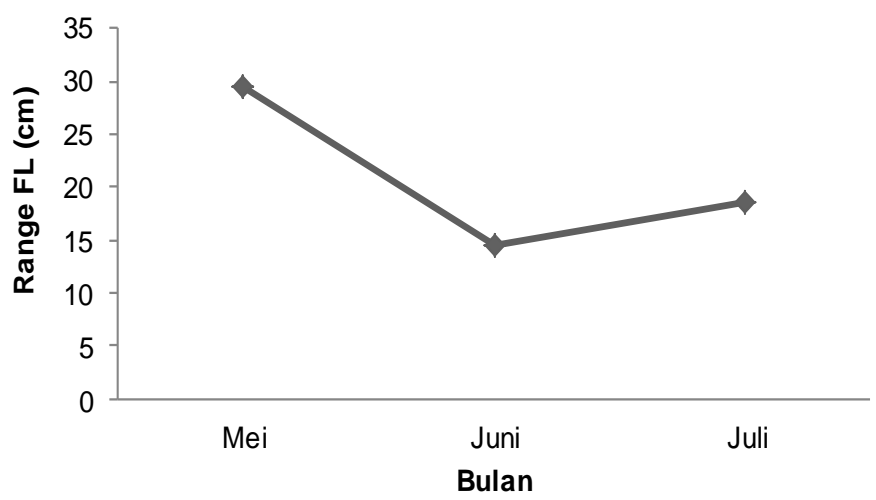

Gambar 4 Kisaran panjang cagak cakalang yang didaratkan di PPI Dufa-Dufa Kota Ternate.

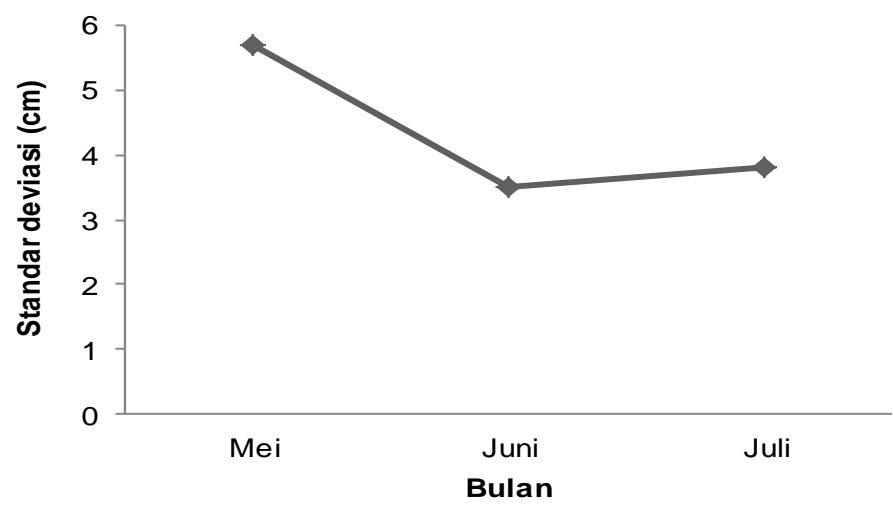

Gambar 5 Standar deviasi panjang cagak cakalang yang didaratkan di PPI Dufa-Dufa Kota Ternate 
Tabel 2 Proporsi sampel cakalang layak dan tidak layak tangkap yang didaratkan di PPI DufaDufa selama 3 bulan (Mei sampai Juli)

\begin{tabular}{lccrc}
\hline \multirow{2}{*}{ Bulan } & \multirow{2}{*}{$\begin{array}{c}\text { Rataan FL Cakalang } \\
\text { Sampel }(\mathbf{c m})\end{array}$} & $\begin{array}{c}\text { Jumlah } \\
\text { (ekor) }\end{array}$ & & \multicolumn{2}{c}{ Proporsi } \\
\cline { 5 - 5 } & 48,99 & 200 & 33,33 & $\begin{array}{c}\text { Layak Tangkap } \\
\text { Tangkap }\end{array}$ \\
\hline Mei & 40,54 & 200 & 0 & 0 \\
Juni & 34,95 & 200 & 0 & 33,33 \\
Juli & Jumlah & $\mathbf{6 0 0}$ & $\mathbf{3 3 , 3 3}$ & $\mathbf{6 6 , 3 3}$ \\
\hline & & & &
\end{tabular}

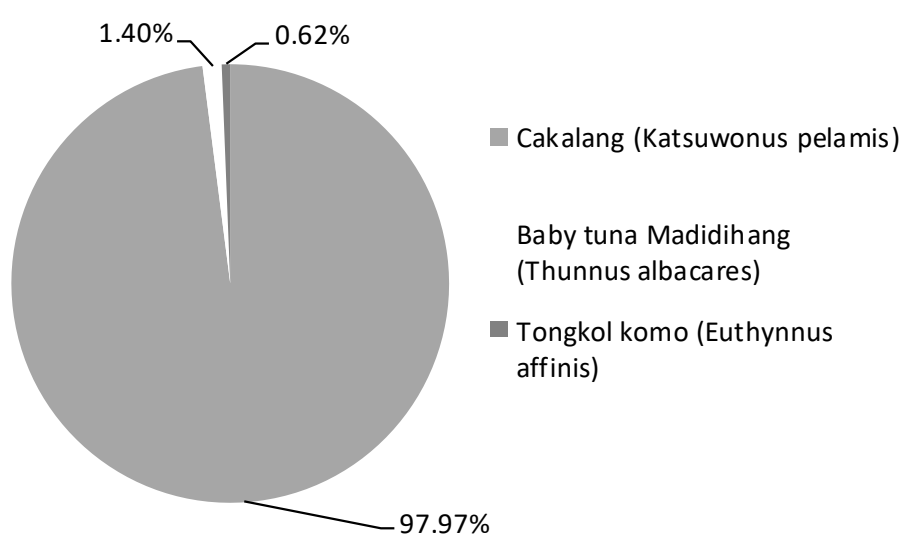

Gambar 6 Komposisi jenis ikan hasil tangkapan huhate yang didaratkan di PPI Dufa-Dufa Kota Ternate selama 3 bulan (Mei sampai Juli)

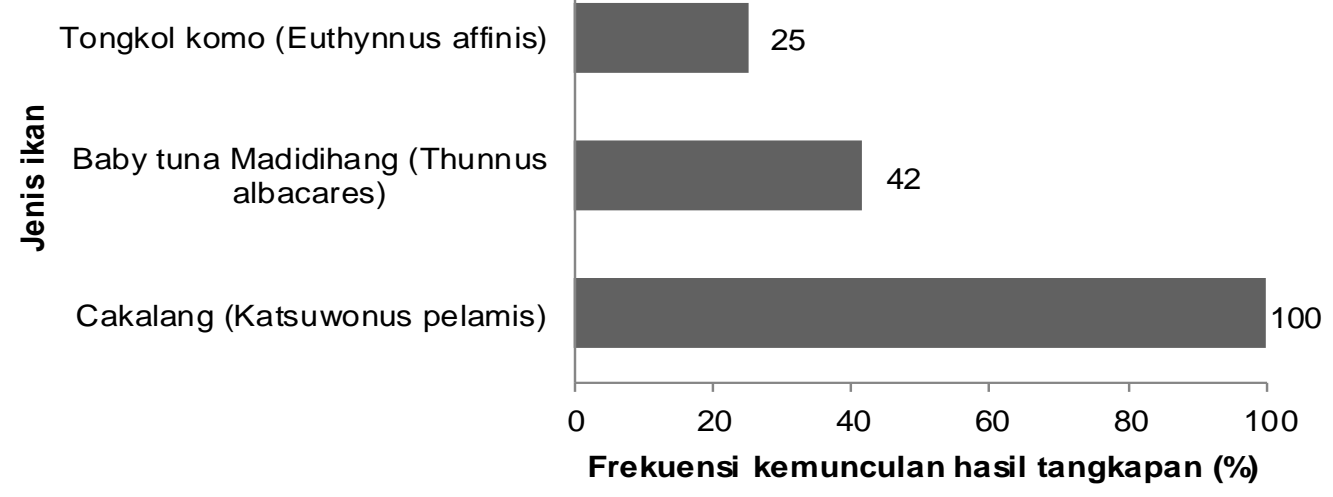

Gambar 7 Frekuensi kemunculan hasil tangkapan huhate yang didaratkan di PPI Dufa-Dufa Kota Ternate Selama 3 bulan (Mei, Juni, dan Juli)

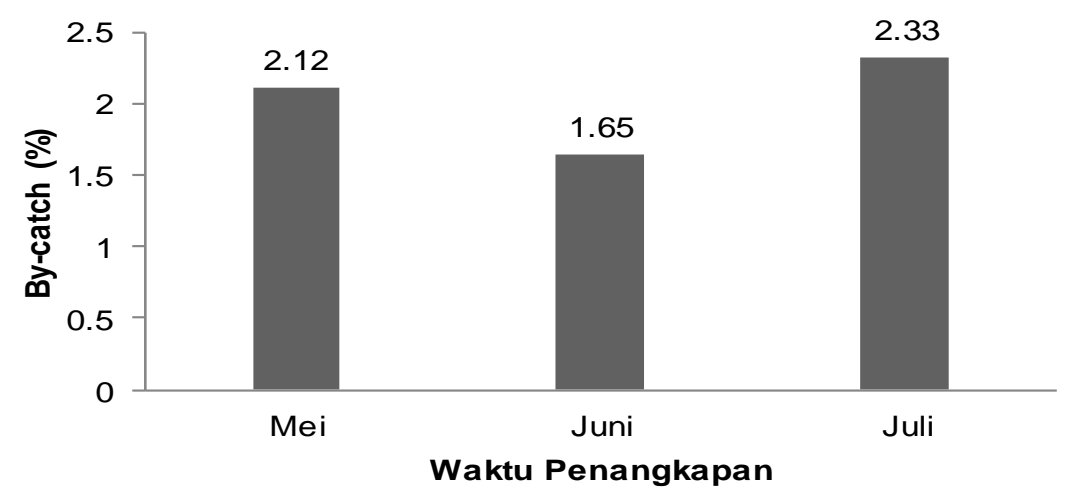

Gambar 8 Persentase hasil tangkapan bycatch huhate yang didaratkan di PPI Dufa-Dufa Kota Ternate Selama 3 bulan (Mei sampai Juli) 


\section{Komposisi Jenis Hasil Tangkapan}

Jenis-jenis ikan yang tertangkap dengan huhate yang didaratkan di PPI Dufa-Dufa Kota Ternate selama penelitian, yaitu: cakalang (Katsuwonus pelamis) dengan persentase sebesar $97,97 \%$, diikuti oleh baby tuna madidihang (Thunnus albacares) dan tongkol komo (Euthynnus affinnis) dengan persentase masing-masing sebesar $1,40 \%$ dan $0.62 \%$ (Gambar 6 ).

\section{Frekuensi Kemunculan Hasil Tangkapan}

Nilai rata-rata frekuensi kemunculan jenis ikan yang tertangkap dengan huhate dan didaratkan di PPI Dufa-Dufa Kota Ternate berturut-turut, yaitu; cakalang (Katsuwonus pelamis) $100 \%$, baby tuna madidihang (Thunnus albacares) $42 \%$, dan tongkol komo (Euthynnus affinnis) 25\% (Gambar 7).

\section{Bycatch dan Discards}

Bycatch huhate yang didaratkan di PPI Dufa-Dufa Kota Ternate selama 3 bulan (Mei, Juni, dan Juli), menunjukkan bahwa pada bulan Mei hasil tangkap sampingan sebanyak 2,13\% dan Juni memiliki hasil tangkapan sampingan yang terkecil, yaitu $1,65 \%$. Hasil tangkapan sampingan terbanyak ditemui pada bulan Juli yaitu $2,33 \%$. Survei terhadap hasil tangkapan yang dibuang kelaut menunjukkan bahwa selama penelitian tidak ditemukan discards (Gambar 8).

\section{Keberlanjutan Perikanan Huhate}

Keberlanjutan perikanan huhate dilakukan secara deskriptif berdasarkan kriteria struktur cakalang yang tertangkap (persentase cakalang tidak dan layak tangkap), persentase bycatch dan discards. Berdasarkan nilai dari persentase ukuran cakalang yang tidak layak tangkap (Tabel 2), maka perikanan huhate memiliki tingkat keberlanjutan yang rendah. Sementara itu, berdasarkan nilai dari persentase bycatch dan discards maka perikanan huhate memiliki tingkat keberlanjutan yang tinggi.

\section{PEMBAHASAN}

Rataan cakalang yang tertangkap dengan huhate yang didaratkan di PPI Dufa-Dufa Kota Ternate selama 3 bulan (Mei, Juni, dan Juli) didominasi ukuran belum layak tangkap, dimana dari 600 ekor sampel cakalang yang diukur memiliki rataan ukuran $\mathrm{FL}$ berkisar antara 34,95 - 40,54 $\mathrm{cm}$ pada bulan Juni dan Juli sebanyak 400 ekor (66,7\%), dan ukuran FL
$48,99 \mathrm{~cm}$ pada bulan Mei sebanyak 200 ekor $(33,33 \%)$. Berdasarkan hasil penelitian Karman et al. (2016) cakalang layak tangkap di perairan barat dan selatan Provinsi Maluku Utara berukuran $43 \mathrm{~cm}$. Selanjutnya hasil penelitian Toatubun at el. (2015) di PPP Tumumpa Manado menunjukkan bahwa komposisi ukuran panjang cakalang terbesar yang tertangkap dengan pukat cincin yaitu pada kelas $30,00-34,99 \mathrm{~cm}$.

Ikan layak tangkap didefenisikan sebagai ikan yang memiliki panjang yang lebih besar dari panjang pertama kali matang gonad (length at first maturity, $L m$ ). Nilai $L m$ cakalang berbeda pada setiap tempat, namun umumnya lebih besar dari $40 \mathrm{~cm}$ (Tabel 1).

Struktur cakalang yang tertangkap dengan huhate dan didaratkan di PPP Dufa-Dufa Kota Termate memiliki nilai persentase ukuran tidak layak tangkap lebih dari 50\% (Tabel 2), maka perikanan huhate memiliki tingkat keberlanjutan yang rendah. Tingginya ukuran cakalang yang tidak layak tangkap menunjukkan, nelayan belum mengetahui bulan penangkapan yang aman untuk keberlanjutan perikanan tersebut. Selain itu juga tingginya ukuran cakalang yang tidak layak tangkap diduga karena daerah penangkapannya di periran sekitar rumpo, hal ini sesuai dengan pernyataan Mallawa et al. (2018), bahwa tingkat keberlanjutan perikanan huhate akan menurun apabila melakukan penangkapan di area rumpon. Berdasarkan ukuran ikan layak tangkap tersebut, Karman et al. (2016), menyatakan bahwa spesifikasi alat untuk menangkap cakalang dapat ditentukan untuk mendukung keberlanjutan perikanan tangkap, misalnya memperbesar ukuran mata pancing huhate dari yang sekarang digunakan (No.2,8) atau dengan penetapan closed season (penutupan musim). Menurut Wang et al. (2012), bahwa terdapat perbedaan struktur ukuran gerombolan ikan cakalang yang berada di area rumpon dan di luar area rumpon, di mana gerombolan ikan di luar rumpon terbentuk berdasarkan ukuran ikan, sedangkan gerombolan ikan di rumpon terbentuk tidak berdasarkan ukuran.

Cakalang yang tertangkap sebelum matang gonad, dapat diduga bahwa ikan tersebut belum sempat memijah sehingga hal ini akan mempengaruhi rekruitmen di daerah penangkapan tersebut. Berdasarkan ukuran ikan layak tangkap, spesifikasi alat untuk menangkap ikan cakalang dapat ditentukan untuk mendukung keberlanjutan perikanan huhate. Misalnya memperbesar ukuran mata pancing huhate dari yang sekarang digunakan atau dengan penetapan closed season (penutupan musim) penangkapan pada musim banyaknya cakalang 
muda yaitu pada bulan Juli. Karman et al. (2016), menyatakan bahwa keberlanjutan perikanan tangkap sebaiknya didukung oleh peraturan yang menetapkan ukuran ikan yang layak tangkap. Salah satu kriteria ikan layak ditangkap adalah memiliki panjang yang lebih besar dari panjang pertama kali ikan matang gonad (length at first maturity, Lm).

Hasil penelitian menunjukkan bahwa persentase bycatch adalah $2.02 \%$ dan tidak ada ikan yang dibuang. Hal ini mengindikasikan bahwa hasil tangkapan lebih banyak yang merupakan ikan target, sementara itu, bycatch yang tertangkap masih memiliki nilai ekonomis yang baik di pasaran.

Meskipun bycatch pada perikanan huhate rendah namun usaha-usaha untuk meminimumkan tetap perlu dilakukan. Salah satu usaha yang bisa dilakukan adalah sortir hasil tangkapan. Apabila ditemukan species yang akan dibuang ke laut, sebaiknya dilakukan dalam keadaan masih hidup. Terhadap habitat alat tangkap yang digunakan tidak menganggu habitat, khususnya habitat karang, karena alat tersebut digunakan di perairan permukaan dan tidak bersentuhan langsung dengan daerah terumbu karang atau dasar perairan.

\section{KESIMPULAN}

Cakalang yang tertangkap huhate di sekitar rumpon perairan Kota Ternate dan didaratkan di PPI Dufa-Dufa didominasi ukuran yang belum layak tangkap yaitu sebesar 66,67. Hasil tangkapan didominasi ikan target yaitu cakalang sebesar $97,97 \%$, sedangkan bycatch berupa baby tuna madidihang sebesar 1,40\% dan tongkol komo yang hanya 0,62\%. Apabila dilihat dari persentase per bulan, bycatch yang terbanyak ditemui pada bulan Juli yaitu $2,33 \%$. Selama penelitian berlangsung, tidak ditemukan hasil tangkapan yang dibuang ke laut (discards). Berdasarkan persentase ukuran layak tangkap, perikanan huhate memiliki tingkat keberlanjutan yang rendah sedangkan berdasarkan nilai dari persentase bycatch dan discards maka perikanan huhate memiliki tingkat keberlanjutan yang tinggi.

\section{SARAN}

Nelayan menggunakan huhate untuk menangkap cakalang dengan alat bantu yang disebut rumpon dan cakalang yang tertangkap di perairan sekitar rumpon didomasi oleh ikanikan muda (belum layak tangkap), hal ini memberikan indikasi kemungkinan perairan di sekitar rumpon menjadi tempat pemijahan cakalang oleh karena itu perlu ditetapkan ukuran mata pancing yang khusus digunakan untuk menangkap cakalang di sekitar rumpon dan melakukan penutupan musim pada saat banyaknya ukuran cakalang muda.

\section{UCAPAN TERIMA KASIH}

Penulis mengucapkan terima kasih kepada Rektor Universitas Khairun dan Ketua LPPM yang telah membantu dana penilitan, sehingga penelitian dan artikel ini dapat diselesaikan. Tak lupa juga penulis mengucapkan terima kasih kepada para reviewer yang telah banyak memberikan masukan dan komentar untuk memperbaiki tulisan ini.

\section{DAFTAR PUSTAKA}

Gigentika S, Wisudo HS, Mustaruddin. 2014. Strategi Pengembangan Perikanan Cakalang di Kabupaten Lombok Timur Provinsi Nusa Tenggara Barat. Marine Fisheries. 5(1): 27-40.

Jamal M, Sondita MAF, Haluan J, Wiryawan B. 2011. Pemanfaatan Data Biologi Cakalang (Katsuwonus pelamis) dalam Rangka Pengelolaan Bertanggung Jawab di Perairan Teluk Bone. J. Natur Indonesia. 14(1):107-113.

Karman A, Martasuganda S, Sondita MFA, Baskoro MS. 2014. Capture Fishery Biology of Skipjack in Western and Southern Waters of North Maluku Province. International J. of Sciences: Basic and Applied Research. 16(1): 432-488.

Karman A, Martasuganda S, Sondita MFA, Baskoro MS. 2016. Basis Biologi Cakalang sebagai Landasan Pengelolaan Perikanan Berkelanjutan di Provinsi Maluku Utara. J. IImu dan Tek. Kel. Tropis. 8(1): 159-173.

Kasmawati, Ardiana. 2015. Analisis Keberlanjutan Perikanan Bagan Tancap Berdasarkan Aspek Biologi dan Ekonomi. J. Octopus. 4 (1): 351-357.

Mallawa A. 2013. Dinamika Populasi dan Pendugaan Stok. Bagian I : Dinamika Populasi Biota Perairan. Buku Ajar, LKPP UnHas. Makassar.

Mallawa A. 2016. Size Structure of Skipjack (Katsuwonus pelamis) Captured by Pole And Line Fishermen Inside And Outside of Fish Aggregation. International J. of Scientific \& Technology Research. 5(9): 159-163. 
Mallawa A, Amir F, Safruddin, Mallawa E. 2018. Keberlanjutan Teknologi Penangkapan Ikan Cakalang (Katsuwonus pelamis) di Perairan Teluk Bone, Sulawesi Selatan. Marine Fisheries. 9(1): 95-108.

Sudirman, Hade AR, Sapruddin. 2011. Perbaikan Tingkat Keramahan Lingkungan Alat Tangkap Bagan Tancap Melalui Perbaikan Selektivitas Mata jaring. Bull. Penelit. LP2M. 2(1):47-64.

Toatubun N, Wenno J, Labaro IL. 2015. Struktur Populasi Ikan Cakalang Hasil Tangkapan Pukat Cincin yang Didaratkan di Pelabuhan Perikanan Pantai Tumumpa Kota Manado. J. IImu dan Teknologi Perikanan Tangkap. 2(2): 73-77.
Tuli M, Boer M, Adrianto L. 2014. Analisis Sumberdaya Cakalang (Katsuwonus pelamis) di Perairan Kabupaten Pohuwato, Provinsi Gorontalo. Marine Fisheries. 5(1): 57-66.

Utami PB, Kusumastanto T, Zulbainani N. 2015. Pengelolaan Perikanan Cakalang Berkelanjutan dengan Pendekatan Bioekonomi di Kabupaten Flores Timur. Marine Fisheries. 6(1): 1-11.

Wang X, Xu L, Chen Y, Zhu G, Tian S, Zhu J. 2012. Impact of Fish Aggregation Deviceson Size Structures of Skipjack Tuna (Katsuwonus Pelamis). J. Aquat. Ecol. 46(2) :343 - 352. 